Equalita, Vol. 1 Issue 1, Agustus 2019

Avaliable online at http://syekhnurjati.ac.id/jurnal/index.php/equalita/article/view/5163

Diterbitkan oleh Pusat Studi Gender dan Anak LP2M IAIN Syekh Nurjati Cirebon, Indonesia

\title{
FEMINISME DALAM PESANTREN: NARASI PEMBERDAYAAN PEREMPUAN DI PONDOK PESANTREN BUNTET CIREBON
}

\author{
Wardah Nuroniyah \\ IAIN Syekh Nurjati Cirebon
}

wardah.faza@yahoo.com

\begin{abstract}
- Received: 25 Juli 2019
- Accepted: 21 Agustus 2019

- Published online: 30 Agustus 2019

Abstract: Discourse about women in the pesantren environment is an exclusive issue to be presented both internally in the pesantren and public. Women with various problems in the pesantren environment are a reflection of the "face" of Indonesian Muslim women. The debate between men and women in the study of feminism is often a sensitive topic so it does not rule out discrimination against women. In line with that, the researcher was moved to participate in exploring and driving the empowerment of women in the pesantren environment through research, namely feminism in the pesantren. More real, at one pesantren in Cirebon, the Buntet boarding school. Using a qualitative approach and using the structural-functional theory the results of the research found the fact that the role of women in the Buntet Cirebon boarding school is still limited to participatory in a functional structural framework. This role still limits the capacity of men and women in the pesantren environment. Whereas the development of feminism values in the Buntet Cirebon boarding school applies formally. In the sense that there has been a formal recognition that women have room to develop their roles and participation in the pesantren environment. While culturally, there are still remnants of the patriarchal culture that are not easily removed from pesantren even though there have been changes little by little. The influence of feminist values on the doctrines and traditions of the pesantren in the Cirebon Buntet Islamic boarding school is the emergence of a more egalitarian understanding of the existence of women. Likewise, with the pesantren tradition, there began to be a shift from traditions that prioritized the role of men from women to the tradition of egalitarianism in looking at women. In the next stage, women are no longer considered as subordinate men but become free and independent persons.
\end{abstract}

\section{Keywords: Women, Feminism, Gender, Pesantren, Cirebon}

Abstrak: Diskursus mengenai perempuan di lingkungan pesantren menjadi persoalan yang eksklusif untuk disajikan baik pada internal pesantren maupun di muka publik. Perempuan dengan berbagai problematikanya dalam lingkungan pesantren merupakan sebuah cerminan "wajah" perempuan Islam Indonesia. Perdebatan antara laki-laki dan perempuan dalam kajian feminisme sering menjadi topik yang sensitif sehingga tidak menutup kemungkinan adanya diskriminasi terhadap perempuan. Sejalan dengan itu, peneliti tergerak untuk ikut mendalami dan menggerakkan pemberdayaan perempuan dalam lingkungan pesantren melalui penelitian yaitu feminisme dalam pesantren. Lebih riilnya, pada salah satu pesantren di Cirebon yaitu pondok pesantren Buntet. Dengan Pendekatan kualitatif dan menggunakan teori struktural-fungsional hasil penelitan menemukan fakta bahwa peranan perempuan di pondok pesantren Buntet Cirebon masih sebatas partisipatoris dalam kerangka struktural fungsional. Peran tersebut masih membatasi antara kapasitas laki-laki dan perempuan di lingkungan pesantren. Sedangkan Pengembangan nilai-nilai feminisme di pondok pesantren Buntet Cirebon berlaku secara formal. Dalam artian telah ada pengakuan secara formal bahwa perempuan mendapatkan ruang untuk mengembangkan peranan dan partisipasinya di lingkungan pesantren. Sedangkan secara kultural, masih terdapat sisa-sisa budaya patriarkhi yang tidak mudah dihilangkan dari pesantren meskipun telah ada perubahan sedikit demi sedikit. Adapun 


\section{Wardah Nuroniya}

Pengaruh nilai-nilai feminisme terhadap doktrin dan tradisi pesantren di pondok pesantren Buntet Cirebon adalah munculnya pemahaman yang lebih egaliter terhadap eksistensi perempuan. Begitu pula dengan tradisi pesantren, mulai ada pergeseran dari tradisi yang lebih mengutamakan peran laki-laki dari pada perempuan menjadi tradisi egalitarianisme dalam memandang perempuan. Pada tahapan selanjutnya, perempuan tidak lagi dianggap sebagai subordinat laki-laki tetapi menjadi pribadi yang bebas dan mandiri.

Kata Kunci: Perempuan, Feminisme, Gender, Pesantren, Cirebon

\section{A. PENDAHULUAN}

Perempuan dalam Islam selalu menjadi pembicaraan dan diskursus yang menarik. Dalam sejarah Islam, terdapat beberapa perspektif yang memandang dan menempatkan perempuan secara berbeda. Di antara ragam perspektif itu adalah ulama ortodoks dan konservatif yang menegaskan bahwa peranan perempuan dibatasi di lingkungan rumah saja. ${ }^{1}$ Persepsi di atas tentunya berbeda dengan pendapat modern, yang lebih menempatkan perempuan pada ruang dan kapasitas lebih terbuka dalam kehidupan bermasyarakat. Berdasarkan pada rujukan yang sama pula yaitu Al-Qur'an dan hadis, peranan perempuan sebagaimana dijelaskan dalam Al-Qur'an adalah: (1) peran yang menunjukkan pada konteks sosial, budaya, dan historis di mana seorang perempuan menjalani kehidupannya; (2) peran yang dapat diterima secara universal sebagai suatu fungsi perempuan seperti menyusui dan merawat bayi; (3) peran yang tidak berhubungan dengan jenis kelamin secara langsung seperti peran manusia di bumi. Bahkan, dalam sejarah Islam telah dikenal tokoh-tokoh perempuan yang sangat berpengaruh seperti Ibu Nabi Musa, Maryam, dan Balqis (Ratu Shaba'), meskipun kisahkisah tentang ketauladanan mereka sering tidak dilengkapi dengan visi perempuan dan persoalan gender. ${ }^{2}$ Ketauladanan mereka sebagai representasi perempuan dikaburkan karena dominasi laki-laki yang masih begitu kuat atau lebih tepatnya adalah hidup dalam kungkungan budaya patriarkhi.

Keterbatasan peran perempuan merupakan masalah universal yang banyak terjadi di berbagai negara baik negara Islam maupun negara yang bukan Islam. Dalam konteks Indonesia, pemikiran dan gerakan gender dapat berkembang setelah muculnya perumusan terma-terma agama, khususnya agama Islam. Problematika inilah yang

${ }^{1}$ Asghar Ali Engineer, Pembebasan Perempuan, (terj.) Agus Nuryatno (Yogyakarta: LKiS, 2003), h. 265. Lihat juga, Abdul Rahman Al-Sheha, Woman in the Shade of Islam (ttp.: Islamic Educational Center, 2000), h. 83.

${ }^{2}$ Nurjannah Ismail, Perempuan dalam Pasungan: Bias Laki-laki dalam Penafsiran (Yogyakarta: LkiS, 2003), h. 71-72. Baca juga: Ihsan Ali-Fauzi, Membumikan Al-Qur'an: Fungsi dan Peran Wahyu dalam Kehidupan Masyarakat (Bandung: Mizan, 2002), h. 394. 


\section{Wardah Nuroniya}

mendorong aktivis feminis dan sarjana Muslim Indonesia untuk mengkaji dan melakukan pendidikan serta pendampingan dalam kasus-kasus seputar gender. Salah satu upaya konkret yang dilakukan adalah dengan merekonstruksi khazanah pemikiran dan gerakan Islam terhadap keberadaan perempuan. Beberapa isu-isu yang menjadi perhatian khusus adalah Islam dan hak-hak reproduksi perempuan, Islam dan peran perempuan, kritik terhadap teks-teks agama, mengembangkan fikih perempuan, seksualitas dan kekerasan terhadap perempuan. ${ }^{3}$ Sumber rujukan upaya rekonstruksi itu tidak melulu dari Barat namun dari internal Islam sendiri juga sesuai dengan proses interpretasi yang cukup ketat dan mendalam. Upaya-upaya itu menunjukkan bahwa meningkatnya paham dan gerakan feminis dalam konteks Islam dan keindonesiaan.

Apabila dihubungkan dengan konteks pembangunan Indonesia, maka berhasil atau tidaknya pembangunan di negeri dalam pandangan feminis adalah seberapa jauh perempuan dilibatkan secara aktif dan proporsional dalam pembangunan tersebut, termasuk dalam hal ini adalah yang berkaitan dengan dunia pesantren. Emansipasi perempuan yang sering didengungkan oleh kaum feminis sering terbentur pada rujukan ajaran Islam, yang memang sangat sedikit sekali membahas tentang emansipasi tersebut. Alasannya, bagaimanapun laki-laki dan perempuan memiliki perbedaan kodrat. Dalam Al-Qur'an sendiri telah dijelaskan mengenai perbedaan laki-laki dan perempuan, yang selanjutnya diperjelas oleh hadis-hadis Nabi Muhammad yang mengatur ketentuan hukum waris dan penentuan shaf shalat. ${ }^{4}$ Perihal kodrat ini pula yang sering menjadi rujukan masyarakat yang ada di pesantren, sehingga kajian gender menjadi sesuatu yang masih tabu di beberapa pesantren.

Diskursus mengenai perempuan di lingkungan pesantren menjadi persoalan yang eksklusif untuk disajikan di internal pesantren dan di muka publik. Berdasarkan penelitian terkait yang telah dilakukan seperti Zamakhsyari mengenai jumlah santri perempuan lebih besar daripada santri laki-laki yaitu 60\% berbanding 40\%. ${ }^{5}$ Kemudian Mujamil Qomar menyebutkan beberapa pesantren juga sudah memiliki lembaga dan program yang berorientasi perempuan seperti lembaga bantuan hukum untuk perempuan dan rebana/kasidah. ${ }^{6}$ Abdurrahman Wahid menjelaskan tentang batasan

\footnotetext{
${ }^{3}$ Amelia Fauzia, dkk., Tentang Perempuan Islam: Wacana dan Gerakan (Jakarta: Gramedia, 2004), h. 134.

${ }^{4}$ Jamhari dan Ismatu Ropi (ed.), Citra Perempuan dalam Islam: Pandangan Ormas Keagamaan (Jakarta: PT Gramedia Pustaka Utama, 2003), h. 106.

${ }^{5}$ Zamakhsyari Dhofier, Tradisi Pesantren: Studi tentang Pandangan Hidup Kyai (Jakarta: LP3ES, 1982), h. 54.

${ }^{6}$ Mujamil Qomar, Pesantren: Dari Transformasi Metodologi Menuju Demokratisasi Institusi (Jakarta: Erlangga, 2005), h. 106.
} 


\section{Wardah Nuroniya}

perempuan dalam menunjukkan penampilannya (fashion-nya) atau dengan istilah yang lebih familiar dalam Islam yaitu aurat perempuan. ${ }^{7}$ Beberapa penelitian tersebut tidak serta merta menjadi tajuk utama dalam mainstream penelitian yang berorientasi pada persoalan gender. Kajian tentang perempuan di pesantren cenderung masih normatif dan "tabu" untuk ditelusuri secara mendalam.

Perempuan dengan berbagai problematikanya dalam lingkungan pesantren merupakan sebuah cerminan "wajah" perempuan Islam Indonesia. Perdebatan antara laki-laki dan perempuan mengenai feminis sering menjadi topik yang sensitif sehingga tidak menutup kemungkinan adanya diskriminasi terhadap perempuan. Sejalan dengan itu, peneliti tergerak untuk ikut mendalami dan menggerakkan emansipasi perempuan dalam lingkungan pesantren melalui penelitian tematik yaitu feminisme dalam pesantren. Lebih riilnya, peneliti terjun langsung pada salah satu pesantren di Cirebon yaitu pondok pesantren Buntet. Berdasarkan latar belakang masalah di atas, maka dapat ditentukan rumusan masalah sebagai berikut: 1) Bagaimana peranan perempuan di pondok pesantren Buntet Cirebon? 2) Bagaimana pengembangan nilai-nilai feminisme di pondok pesantren Buntet Cirebon? 3) Bagaimana pengaruh nilai-nilai feminisme terhadap doktrin dan tradisi pesantren di pondok pesantren Buntet Cirebon?

Penelitian ini memiliki kerangka berpikir yang berbentuk feminisme dalam bingkai penelitian perempuan dan pesantren. Teori-teori yang berkenaan dalam penelitian feminisme adalah teori struktural-fungsional, teori sosial-konflik, teori feminisme liberal, teori feminisme marxis-sosialis, teori feminisme radikal, teori ekofeminisme, dan teori psikoanalisa. Dalam penelitian ini peneliti menentukan teori yang paling relevan adalan teori struktural-fungsional. Teori ini merupakan teori sosiologi yang sering digunakan dalam melihat institusi keluarga. Teori ini berangkat dari asumsi bahwa suatu masyarakat terdiri atas beberapa bagian yang saling memengaruhi. Dalam suatu masyarakat terdapat unsur-unsur dasar yang berguna untuk mengidentifikasi fungsi setiap unsur, dan menerangkan bagaimana fungsi unsur-unsur tersebut dalam masyarakat. Tokoh dalam teori ini yang terkenal adalah William F. Ogburn dan Talcott Parsons. Teori ini mengakui adanya segala bentuk keragaman dalam kehidupan sosial. Keragaman ini merupakan sumber utama dari adanya struktur masyarakat dan menentukan keragaman fungsi sesuai dengan posisi seseorang dalam

${ }^{7}$ Abdurrahman Wahid, Menggerakkan Tradisi: Esai-esai Pesantren (Yogyakarta: LKiS, 2001), h. 27. 


\section{Wardah Nuroniya}

struktur sebuah sistem. ${ }^{8}$ Contoh yang sangat terkait dalam penelitian ini adalah dalam pesantren terdapat seseorang yang menjadi pengasuh, pemimpin, sekretaris, bendahara, koordinator departemen, dan lain sebagainya. Adanya perbedaan fungsi dan bahkan perbedaan jenis kelamin bertujuan untuk mencapai tujuan yang telah ditentukan pondok pesantren Buntet Cirebon, bukan karena kepentingan yang bersifat individual. Dalam penataan struktur dan fungsi pesantren ini sangat dipengaruhi oleh budaya, norma, dan nilai-nilai sosial yang telah berkembang dalam lingkungan pesantren tersebut.

\section{Gambar 1.}

\section{Pola Pengelolaan Pesantren Berbasis Gender}

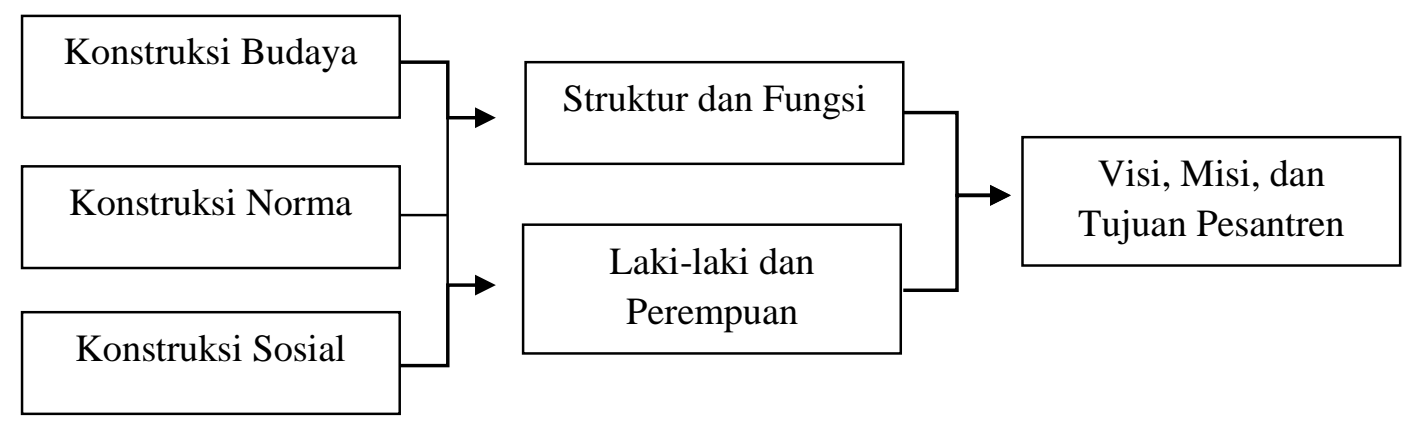

\section{B. METODE PENELITIAN}

Pendekatan dalam penelitian ini adalah pendekatan kualitatif yaitu pendekatan yang lebih menekankan analisis proses penyimpulan deduktif dan induktif serta analisis terhadap dinamika hubungan antar fenomena yang diamati, dengan menggunakan logika ilmiah. Maksudnya adalah pendekatan kualitatif penekanannya tidak pada pengujian hipotesis melainkan pada usaha menjawab pertanyaan penelitian melalui cara-cara berpikir formal dan argumentatif. ${ }^{9}$ Dengan pendekatan tersebut, peneliti mempunyai kewenangan luas untuk menginterpretasi berbagai fakta yang telah diperoleh.

Burns berpendapat bahwa pengungkapan suatu fenomena obyektif dalam penelitian kualitatif ini menekankan pada pentingnya "struktur makna ganda dan analisis holistik". Pandangan ini beranggapan tindakan yang merangkul sejumlah besar makna keterlibatan individu dalam konteks tertentu dan berhubungan dengan persepsi dan interpretasi seseorang terhadap realias yang terjadi di pesantren. Pemahaman ini menyatakan bahwa ilmu sosial adalah usaha subyektif, bukan obyektif, sebagai sarana

${ }^{8}$ Ratna Megawangi, Membiarkan Berbeda: Sudut Pandang Baru tentang Relasi Gender (Bandung: Mizan, 1999), Cet. I, h. 56.

${ }^{9}$ Saifuddin Azwar, Metode Penelitian, h. 5. 


\section{Wardah Nuroniya}

untuk melihat dan memahami pengalaman seseorang dalam konteks tertentu. Pentingnya pengalaman subyektif ini adalah untuk menciptakan kesadaran individu, yang mengandung maksud bahwa penilaian terhadap kejadian adalah konstruksi pribadi dan subyektif dari peranannya di pesantren.

\section{Profil Pondok Pesantren Buntet Cirebon}

Sejarah berdirinya pondok pesantren Buntet, dijelaskan bahwa pesantren ini didirikan oleh Kyai Muqayim pada tahun 1758. Pada awalnya, mbah Muqayim (sebutan untuk Kyai Muqayim bagi anak cucunya) membuka pengajian dasar-dasar Al-Qur'an, bagi masyarakat Desa Dawuan Sela (1 km ke sebelah Barat dari Desa Mertapada Kulon (lokasi pondok pesantren Buntet sejak tahun 1750-an). Tempat berlangsungnya pengajian itu adalah sebuah Panggung Bilik Bambu ilalang yang di dalamnya terdapat beberapa kamar tidur atau pondokan yang dindingnya terbuat dari bambu dan atapnya terbuat dari pohon ilalang (sejenis rumput yang tinggi). Hingga beberapa tahun kemudian keberadaan "Pondok Pesantren Pemula" ini diserahkan kepada K. Muta'ad (menantu R. Muhammad anak mbah Muqayim). Sementara mbah Muqayyim sendiri memilih menjadi mufthi hingga akhir hidupnya di daerah Beji (Pemalang, Jawa Tengah). Sebelum kepergiannya ke Beji, beliau menyerahkan kepemimpinan pondok pesantrennya kepada K. Muta'ad yang juga salah seorang putra Kasepuhan Cirebon dan pernah menjadi penghulu Keresidenan Cirebon. Konon, serah-terima kepemimpinan Buntet Pesantren ini terjadi pada 1785.

Pondok Pesantren Buntet mulai ada perkembangan adalah pada periode kepemimpinan KH. Abdul Jamil (1842-1910) yaitu ketika pertamakali beliau memperbaiki sarana fasilitas yang telah dianggap rapuh, penyusunan jadwal pengajian, penambahan cara atau metode pengajaraan KK yaitu tidak hanya menggunakan metode tradisional seperti metode sorogan dan bandongan tetapi dikembangkan juga cara atau metode lain seperti mujadalah (diskusi) bahkan pada saat itu dikembangkan juga sistem klasikal (madrasi).

Perkembangan berikutnya, sistem madrasi atau sistem persekolahan diformalkan pada saat KH. Abbas Abdul Jamil memimpin Pondok Pesantren Buntet pada 1910-1946, yaitu dengan membuka lembaga pendidikan sekolah dalam bentuk Madrasah Wajib Belajar (MWB), setingkat Taman Kanan Kanak (TK) yang terdiri dari sifir I dan sifir II. Sebagai kelanjutan dari MWB, KH. Abbas Abdul Jamil juga mendirikan Madrasah Wathaniyah Ibtidaiyah (MWI) I setingkat SD. Pada tahun yang sama, KH. Abbas Abdul Jamil juga menerapkan spesialisasi bidang ilmu bagi Kyai maupun ustadz yang mengajar di pondok atau di madrasah yang ada di pesantren Buntet. Perubahan yang dilakukan KH. Abbas 


\section{Wardah Nuroniya}

Abdul Jamil tidak hanya membenahi sarana dan fasilitas, santri yang tampak cerdas dan memiliki kelebihan juga memperoleh perhatian khusus yaitu diberikan biaya untuk melanjutkan ke Makkah atau Madinah.

Pada tahun 1960-an, ketika KH. Mustahdi Abbas memimpin pesantren Buntet, dibuka MTs Putra (Muallimin) dan MTs Putri (Muallimat) sebagai kelanjutan dari MIW. Pada perkembangan berikutnya, MTs Putra dan Putri ini berubah menjadi Pendidikan Guru Agama (PGA) Putra dan Putri yang masa belajarnya empat tahun (tapi ujian negaranya mengikuti MTs N yang masa belajarnya tiga tahun). Sebagai kelanjutan dari MTs/ PGA Putra dan Putri, KH. Mustahdi Abbad (kepemimpinan periode 1946-1975) sebagai pembina pesantren Buntet memprakarsai berdirinya Madrasah Aliyah (MA) Putra dan Putri pada 1968 yang kemudian pada 1971 MA Putra dan Putri ini dinegerikan menjadi Madrasah Aliyah Agama Islam Negeri (MAAIN). MAAIN seluruh Indonesia (termasuk MAAIN Buntet) berdasarkan SK Menag berubah menjadi Madrasah Aliyah Negeri atau MAN.

Dengan demikian, pesantren Buntet selama tiga dasawarsa (1946-1979) telah mengalami perubahan dan pembaharuan yang sangat pesat terutama dalam bidang pendidikan sekolah yakni sejak diprakarsai MWB kemudian MIW, dilanjutkan berdirinya MTs Muallimin dan muallimat dan terakhir MA yang kemudian dinegerikan menjadi MAN. Kenyataan ini menunjukkan bahwa, Kyai dan para pembina pesantren Buntet selalu berupaya meningkatkan dan memikirkan bentuk dan jenis pendidikan yang sesuai dengan kemauan dan perkembangan jaman. ${ }^{10}$

\section{Keadaan Kyai dan Santri}

Kyai yang ada di komplek Buntet pesantren dapat dikelompokkan ke dalam dua kelompok yaitu, Kyai pendatang dan Kyai keturunan mbah Muqayim. Kyai pendatang adalah mereka yang bukan penduduk atau bukan keturunan mbah Muqayim, melainkan santri atau orang lain yang karena memiliki keahlian tertentu terutama berkemampuan dalam menguasai dan memahami KK sehingga dijadikan menantu Kyai. Sedangkan Kyai keturunan mbah Muqayim adalah mereka yang secara langsung atau tidak langsung, ada garis keturunan dengan mbah Muqayim baik yang ada di dalam mau pun yang ada di luar komplek pondok pesantren Buntet seperti antara lain Kyai yang ada di pondok pesantren Gedongan, pesantren Munjul. Pengelompokkan ini didasarkan atas pertimbangan faktor

${ }^{10}$ Dokumentasi diperoleh dari pondok pesantren Buntet Cirebon, diambil tanggal 10 September 2017. 


\section{Wardah Nuroniya}

psikologis dan sosiologis yang dilakukannya dalam upaya memajukan pendidikan di pondok pesantren Buntet.

Data menunjukkan, secara keseluruhan, Kyai yang ada di komplek Buntet Pesantren adalah berjumlah 50 orang dengan latar belakang pendidikan dan keahlian. Di pondok pesantren Buntet terdapat 37 asrama atau pondok, 38,54 \% pondok yang ada di Kabupaten Cirebon terpusat di Pesantren Buntet. Dari ke-37 asrama tersebut, yang memiliki 100 orang santri lebih ada enam asrama dan 31 asrama yang memiliki kapasitas di bawah 100 orang santri. Berdasasarkan dokumentasi yang diperoleh peneliti, terdapat keterangan bahwa, "Ketentuan yang telah disepakati bersama antar Kyai pada 1982 adalah, setiap asrama seyogyanya dibantu lima orang ustadz baik dari lingkungan sendiri ataupun mendatangkan dari asrama lain" (Wawancara, 14-02-2017). Karena itu, ustadz yang ada di komplek Buntet Pesantren berjumlah 170 orang ustadz. Tugas ustadz, selain mengajarkan dasar-dasar al-Qur'an dan KK dasar seperti kitab sufinah al-najah, sulam altaufiq, tijan al-dharara; khairun al-nisa, tajwid, 'awamil atau al-jurumiyah, juga membimbing santri dalam berbagai bentuk keterampilan seperti belajar khithabah (berpidato), berorganisasi atau kepemimpinan. Dengan demikian, jumlah Kyai dan asatidz Pesantren Buntet adalah 217 orang, maka dari 51 orang Kyai yang ada di pondok pesantren Buntet sebagian besar (92 \%) atau 43 orang adalah "Kyai tua” yang usianya di atas 40 tahun dan hanya sembilan orang (8 \%) saja yang termasuk "Kyai muda" yang usianya di bawah 40 tahun. Ini menunjukkan bahwa, Pesantren Buntet dibimbing dan dibina oleh para Kyai atau pembina yang telah memiliki pengetahuan keagamaan yang mendalaman sesuai dengan bidang pengetahuannya.

Latar belakang pendidikan, sebagain besar (25 orang) adalah alumnus Pesantren Buntet atau belajar pada orang tua/keluarganya baik di Pondok Pesantren Gedongan dan Pondok Pesantren Benda yang kemudian melanjutkan ke Universitas Darul Ulum (Arab), ke Universitas Al-Azhar, ke London atau ke Perancis; delapan orang Kyai alumnus Pesantren di Sarang, Pesantren Lasem, Pondok Pesantren Krapyak (Yogyakarta) dan sembilan orang Kyai alumnus Pondok Pesantren Lirboyo dan Pondok Pesantren Kediri.

Santri Pesantren Buntet adalah, para pelajar dan mahasiswa yang tinggal di asrama besar ataupun di rumah-rumah Kyai yang ada di komplek Buntet Pesantren. Karena itu, pelajar atau mahasiswa yang tidak mondok di komplek "Buntet Pesantren" tidak termasuk santri pondok pesantren Buntet. Pada saat penelitian ini dilakukan, jumlah santri Pesantren Buntet adalah 1.496 orang santri terdiri dari 908 orang santri 


\section{Wardah Nuroniya}

pria dan 588 orang santri wanita. Sebagian besar adalah para pelajar dan mahasiswa AKPER yang mesantren di asrama atau rumah Kyai.

Santri pondok pesantren Buntet adalah mereka yang tinggal di rumah-rumah Kyai; mereka belajar dan memperoleh pengawasan Kyai. Kenyataan ini berbeda dengan keadaan santri di beberapa pondok pesantren tradisional lain yang biasanya tinggal secara mandiri di pondok pesantren. Santri pondok pesantren Buntet, menurut Drs. H. Anis Mansur, jika dilihat dari statusnya, maka dapat dikelompokkan ke dalam tiga kelompok yaitu 1) santri muqim (yang tinggal di asrama), 2) santri rumah dan 3) santri dalem. Santri Muqim yaitu, mereka yang tinggal di asrama besar (asbes) yang ada di komplek Buntet pesantren. Untuk tinggal di asrama besar, mereka wajib mentaati semua paraturan yang dibuat oleh pimpinan asrama. Santri Rumah ialah mereka yang tinggal di rumah-rumah Kyai. Mereka harus mengikuti semua kegiatan yang dilaksanakan di lingkungan rumah Kyai. Sedangkan santri Dalem ialah, mereka (anak yatim-piyatu atau anak terlantar) yang orang tuanya tidak mampu membiayai anak-anaknya untuk belajar tetapi berkeinginan kuat agar anak-anaknya dapat memasuki lembaga pendidikan madrasah ataupun mesantren. Santri dalem, biasanya tinggal atau turut serta dengan/di rumah Kyai (sebagai santri rumah). Karena mereka tidak membayar apapun, maka ia diberi pekerjaan seperti memasak untuk santri lain termasuk dia; menjadi tukang kebun, memelihara ternak atau hewan atau menjaga toko milik Kyai/keluarganya. Di lingkungan asramanya, mereka diperlakukan dan diperhatikan sama sebagaimana santri lainnya, hanya saja mereka tidak dimintai iuran asrama ataupun iuran madrasah. ${ }^{11}$

Jika dilihat dari tempat tinggalnya, masih menurut Drs. H. Anis Mansur, sebagian besar santri di Pesantren Buntet adalah santri muqim yaitu mereka yang tinggal (untuk jangka waktu tertentu) di asrama besar ataupun di rumah-rumah Kyai. Dari 1.496 orang santri, 124 orang di antaranya adalah santri kalong (berasal dari daerah tetangga Buntet pesantren) yang mengikuti pengajian al-quran atau KK dasar, selebihnya adalah mereka yang datang dari berbagai daerah, sebagian besar berasal dari Jawa Barat khususnya wilayah III Cirebon (Kota/Kabupaten Cirebon, Majalengka, Kuningan dan Indramayu), selebihnya ada yang datang dari daerah Priyangan Timur yaitu Ciamis, Tasikmalaya dan Sumedang, dari Jawa Tengah (Pekalongan, Tegal, Brebes dan Purwokerto), DKI Jakarta, Lampung, Sumatera Utara bahkan ada empat orang santri yang berasal dari Timur Timur. ${ }^{12}$

\footnotetext{
${ }^{11}$ Dokumentasi diperoleh dari pondok pesantren Buntet Cirebon, diambil tanggal 10 September 2017.

12 Dokumentasi diperoleh dari pondok pesantren Buntet Cirebon, diambil tanggal 10 September 2017.
} 


\section{Pemikiran Kyai Buntet tentang Bentuk Pendidikan}

Pesantren Buntet, sebagaimana sebagian besar pesantren salaf di Indonesia, pada awal berdirinya bukan sebagai reaksi atas persoalan ataupun tuntutan masyarakat atas tujuan perubahan sosial sekitarnya; melainkan lebih merupakan orientasi pengabdian. Orientasi pengabdian ini tentu saja karena kondisi pribadi mbah Muqayyim adalah para pejuang dan kebutuhan masyarakat saat itu membutuhkan pengabdian dari seseorang yang mampu dijadikan sebagai figur pemersatu. Dengan demikian, pemikiran awal berdirinya pesantren Buntet adalah karena niat ikhlas dan pengabdian mbah Muqayyim yang didukung oleh segelintir masyarakat setempat, dan bukan sebagai respon sosial dan usaha transformasi kultural. Keadaan ini belangsung hingga kepemimpinan K. Muta'ad yang masih berorientasi kepada pengabdian, di samping karena kapasitas kepemimpinan tunggal (single management) juga keadaan masyarakat yang masih menghadapi tekanan dari penjajah.

Pemikiran dan orientasi Pesantren Buntet mulai ada perubahan, ketika KH. Abdul Jamil memimpin Pesantren Buntet pada 1842-1910. Walaupun bentuk kepemimpinannya masih bersifat single management tapi tampak terjadi adanya perubahan bahkan pergeseran orientasi. Perubahan yang terjadi saat itu ditandai dengan dibukanya sistem pendidikan madrasah (persekolahan), sehingga baik metode maupun penyelenggaraan pendidikannya mulai menyesuaikan dengan lembaga pendidikan modern yaitu dibentuknya kepemimpinan madrasah, digunakan kelas, penjadwalan mata pelajaran dan spesialisasi guru serta ditentukan perjenjangan dalam pendidikan. Perubahan pemikiran dan orientasi secara besar-besaran, tampak ketika Pondok Pesantren Buntet dipimpin K.H. Abbas Abdul Jamil (1910-1946) yaitu perubahan atau pergeseran sistem pondok pesantren dari sistem salafy murni berubah menjadi sistem pondok pesantren semi modern (khalafy). Perubahan pemikiran dan pergeseran orientasi ini dilanjutkan oleh generasi berikutnya, hingga generasi KH. Abdullah Abbas (1989- sekarang).

Pada kepemimpinan KH. Abdullah Abbas, telah ditempuh beberapa kebijakan, di antaranya pertama, tidak lagi menerapkan sistem single management ini ditandai dengan telah dibentuk Yayasan Pendidikan Islam (YPI) pada 1992. Kedua, Pesantren Buntet bukan lagi sebagai Pesantren Salafi tetapi telah menjadi Pesantren Terpadu antara pesantren salaf dan pesantren modern) yaitu dengan telah dibukanya lembaga-lembaga pendidikan keterampilan seperti pada tahun ajaran 1995/1996 Pesantren Buntet mendirikan Madrasah Aliyah Khusus (MAK) yang dalam proses belajar-mengajarnya 


\section{Wardah Nuroniya}

lebih menekankan kepada keterampilan berbahasa asing, dan pada tahun akademik 1996/1997 telah didirikan lembaga pendidikan tinggi AKPER yang dalam kurikulumnya lebih menekankan kepada keterampilan perawat kesehatan (Dokumen "Pondok Pesantren Buntet" tahun 1998 yang dirangkum penulis).

Melalui YPI, segala kebijakan yang berkaitan dengan pendidikan dan kepesantrenan selalu dimusyawarahkan di kalangan pengurus Yayasan. Sebagai tindak lanjut, hasil musyawarah itu kemudian disosialisasikan kepada masyarakat umum. Tidak hanya itu, semua kebijakan dan informasi publik (public information) dikembalikan kepada YPI. Kenyataan ini mencerminkan bahwa, pondok pesantren Buntet terbuka untuk umum dan menerima saran pendapat dari masyarakat, baik dalam bentuk kelembagaan maupun kurikulum pendidikan. Jadi para Kyai "Buntet" dalam membina Pesantren Buntet, telah mengalami beberapa perubahan, dan setiap perubahan ditentukan oleh visi pimpinan dan misi kelembagaan yang selalu mengikuti perkembangan jaman dan kemauan masyarakat. ${ }^{13}$

\section{Upaya Kyai dalam memenuhi tuntutan masyarakat}

Ada dua upaya nyata yang dilakukan Kyai Buntet dalam memenuhi tuntutan masyarakat yaitu: pertama, merubah visi dan orientasi pendidikan, dan kedua mengadakan kerja sama dengan beberapa lembaga pendidikan.

Merubah visi dan orientasi pendidikan diupayakan para Kyai, karena tuntutan masyarakat yang menginginkan agar lembaga-lembaga pendidikan yang ada di Pondok Pesantren Buntet tidak hanya mengajarkan materi pengetahuan keagamaan tetapi juga materi pengetahuan umum dan teknologi (keterampilan terapan). Dalam hal ini, upaya nyata yang dilakukan adalah, lembaga-lembaga pendidikan yang telah ada dan berorientasi keagamaan dikembangkan menjadi lembaga pendidikan keagamaan bersifat umum dan kejuruan. Misalnya Madrasah Aliyah pada 1967-1970 masih bersifat diniyah (keagamaan), pada 1971 hingga sekarang dikembangkan menjadi madrasah aliyah bersifat umum yakni di samping mengajarkan mata pelajaran keagamaan diajarkan juga mata pelajaran "umum" seperti bahasa Inggris, bahasa Indonesia, matematika, biologi, kimia, fisika, sejarah umum, geografi, akuntansi, dan lain-lain; bahkan pada 1997/1998 Pesantren Buntet membuka lembaga pendidikan yang bersifat pengembangan kejuruan melalui AKPER.

${ }^{13}$ Dokumentasi diperoleh dari pondok pesantren Buntet Cirebon, diambil tanggal 10 September 2017. 


\section{Wardah Nuroniya}

Kenyataan di atas sangat memengaruhi dan bahkan berdampak buruk terhadap pergaulan atau hubungan "Kyai-santri" di asrama dan "guru-murid" di madrasah. Demikian juga dalan menjalin hubungan silang "Kyai-murid" di madrasah atau "gurusantri" di asrama. Dampak negatif yang akan terjadi adalah:

\section{1) Demoralisasi}

Di lingkungan pondok pesantren tradisional, Kyai dan keluarganya biasanya dipadang sebagai orang tua kedua yang harus dihormati setelah kedua orang tuanya di rumah; Kedua orang tuanya yang di rumah dihormati adalah, karena merekalah yang menjaganya, merawat kesehatannya, membesarkan dan membiayai pendidikannya hingga ke jenjang pendidikan tertinggi. Sedangkan Kyai (dan keluarganya) di pondok pesantren dihormati adalah, karena ialah yang mengajarkan kebaikan dan yang selalu mengingatkan agar belajar dengan baik, beribadah dengan tekun dan berperilaku yang baik. Bahkan lebih dari itu, bagi santri tertentu ada yang menghormati Kyai karena nasihat dan bimbingannya lah sehingga ia terselamatkan dari kebodohan dan kesengsaraan di dunia maupun akhirat.

Suasana dan kenyataan tersebut dapat diperhatikan pada beberapa asrama yang Kyainya secara full time memberikan nasihat dan perhatian khusus kepada santrinya terutama dalam pergaulan (inilah yang dimaksud bahwa, hubungan Kyaisantri berlangsung selama 24 jam, baik posisi Kyai sebagai pendidik asrama, pengajar di madrasah maupun sebagai wakil kedua orang tuanya di pondok); tapi bagi Kyai yang tidak memperhatikan secara khusus kepada santrinya (karena kesibukan organisasi maupun kesibukan lainnya), maka kemungkinan ada santrinya yang ketika menjadi santri yunior ia selalu mentaati dan menghormati Kyainya tetapi setelah merasa menjadi santri senior ia (mengalami perubahan fisik dan mental akibat dari pergaulan di madrasah ataupun di rumah) mulai berani melanggar tata tertib asramanya hingga melakukan perkataan ataupun perbuatan yang bersifat "memalukan".

Demoralisasi yang tampak pada asrama yang kurang memperoleh perhatian khusus dari Kyainya adalah, meninggalkan kebiasaan-kebiasaan baik yang selalu diperintahkan Kyainya. Kebiasaan-kebiasaan baik itu antara lain shalat fardlu lima waktu dilaksanakan dengan tepat waktu dan berjamaah, tadarrus al-quran setelah shalat berjamaah, shaum sunah Senin dan Kamis, memakai kain sarung dan peci hitam (santri putra) dan berjilbab (santri putri) di mana pun mereka berada, berkata jujur dan saling menghargai sesama santri.

2) Sulit Dicapai Obyektivitas 


\section{Wardah Nuroniya}

Dampak buruk lain yang ditimbulkan dari karakter ganda adalah, sulit dicapainya penilaian hasil prestasi belajar yang obyektiv bagi "Kyai-guru" yang mengajar di suatu lembaga pendidikan di mana beberapa murid di antaranya adalah santrinya di asrama. Dengan kalimat lain, secara psikologis Kyai yang menjadi guru pada suatu madrasah, tidak akan obyektiv memberi nilai prestasi belajar dengan "apa adanya" kepada muridnya yang adalah santrinya sendiri. Padahal, sebagian dari murid MTs NU, MA NU dan MAN adalah santri yang mesantren di rumah-rumah Kyai atau sebagian dari guru yang mengajar di MTs NU atau MA NU adalah para Kyai yang rumahnya ditempati para muridnya. ${ }^{14}$

\section{Pendukung dan Penghambat Pembaharuan}

Kyai Buntet dipelajari dari corak pemikirannya, mereka dapat dikelompokkan ke dalam tiga kelompok yaitu: kelompok konservatif, kelompok tradisionalis dan kelompok modernis. Terjadi pengelompokkan ini, terutama disebabkan latar belakang pendidikan dan pondok pesantren yang pernah dimasukinya. Penyebab lainnya, kemungkinan kecil, adalah karena perbedaan kecenderungan dalam mendukung partai politik.

Kelompok Kyai konservatif, adalah para Kyai Buntet yang menginginkan agar Pesantren Buntet berjalan secara apa adanya sehingga makna "tradisi suci pondok" seperti shalat berjamaah, tadarrus al-quran ba'da shalat fardlu, pengajian KK dan rasa hormat santri terhadap Kyainya merupakan perwujudan dari kekharismahan dan kesalehan tidak akan ternodai oleh kemajuan dan perkembangan jaman. Mereka ini adalah para Kyai Buntet yang menekuni bidang thariqah yang selama ini menjadi salah satu "kebesaran" nama Pondok Pesantren Buntet. Mereka khawatir, jika Pondok Pesantren Buntet mengikuti perkembangan jaman, maka etika santri dan pengabdian Kyai yang selama ini merupakan ciri khas pondok akan semakin terpinggirkan atau bahkan terjadi degradasi moral.

Kelompok Kyai tradisionalis adalah, para Kyai Buntet yang tidak banyak memiliki gagasan untuk memajukan Pondok Pesantren Buntet, tetapi mereka tidak berusaha menjadi penghalang atau penghambat ide atau pemikiran Kyai modernis. Bahkan mereka selalu siap mendukung dan turut serta dalam melaksanakan ide atau pemikiran itu. Mereka adalah para pembina santri dan pengajar al-quran dan KK tradisional di lingkungan rumahnya. Sebagian besar dari mereka adalah, keturunan mbah Muqayyim atau kerabat dari pimpinan Pondok Pesantren Buntet.

${ }^{14}$ Dokumentasi diperoleh dari pondok pesantren Buntet Cirebon, diambil tanggal 10 September 2017. 


\section{Wardah Nuroniya}

Sedangkan kelompok Kyai modernis adalah, para Kyai Buntet yang karena latar belakang pendidikan, pengalaman atau pergaulan melalui organisasi sehingga mereka selalu membandingkan dengan keberadaan pondok atau lembaga pendidikan lain yang kemudian ingin diterapkan di lembaga yang dibinanya. Kyai Buntet yang tergolong kelompok modernis adalah para Kyai muda dan aktivis pada suatu organisasi (kemasyarakatan atau sosial-politik); atau para Kyai sepuh (sebagian dari mereka adalah pengurus NU) tetapi berpikiran ke depan dalam upaya memperjuangkan dan memajukan Pondok Pesantren Buntet.

Di antara ketiga kelompok tersebut, yang sering saling-silang pendapat dalam menentukan kebijakan LPI atau YPI adalah kelompok konservatif dan kelompok modernis. Berkaitan dengan pro-kontra dalam melakukan berbagai pergeseran visi dan innovasi lembaga, yang sering dianggap sebagai penghambat adalah para Kyai yang bercorak pemikiran konservatif, yaitu mereka yang berharap agar segala kebijakan yang dikeluarkan oleh pimpinan selalu berpijak kepada kepentingan "dalem”. Sedangkan para Kyai tradisionalis, biasanya selalu mendukung terhadap gagasan dan kebijakan yang mengarah kepada perbaikan lembaga (LPI dan YPI). ${ }^{15}$

\section{Orientasi Pendidikan Pesantren Buntet}

Pada awalnya, lembaga pendidikan yang ada di lingkungan Pondok Pesantren Buntet adalah jenis pendidikan keagamaan berbentuk madrasah. Di samping itu, telah ada jauh sebelum itu yaitu, "lembaga sosial keagamaan" berupa pengajian dasar-dasar alquran dan KK tingkat dasar bagi masyarakat Buntet sekitarnya, yang keberadaan dan perkembangannya terus dipertahankan. Melalui kedua lembaga pendidikan keagamaan inilah para santri belajar tentang ilmu pengetahuan keagamaan.

Selanjutnya para Kyai dan pengelola Pondok Pesantren Buntet dengan penuh kesungguhan mereka berjuang melakukan berbagai revisi dan innovasi atau perubahan. Revisi yang dilakukan para "Kyai Buntet" adalah berusaha menjadikan "lembaga sosial keagamaan" menjadi sebuah sistem lembaga kependidikan. Sedangkan innovasinya, melakukan berbagai perubahan dan mengimplementasikan visi yang telah diupayakannya itu dalam bentuk mendirikan beberapa lembaga pendidikan -baik dalam bentuk madrasah, sekolah umum ataupun sekolah kejuruan. Dari sinilah diketahui bahwa KH. Abbas Abdul Jamil mendirikan MWB, MWI, KH. Mustahdi Abbas (MTs NU Putra dan Putri/PGA, MA, MAN), KH. Mustamid Abbas (MA NU Putra dan Putri) dan KH. Abdullah

${ }^{15}$ Dokumentasi diperoleh dari pondok pesantren Buntet Cirebon, diambil tanggal 10 September 2017. 


\section{Wardah Nuroniya}

Abbas (MAK, AKPER) adalah sebagai upaya untuk memperbaiki kekurangan-kekurangan yang ada pada sekaligus memenuhi tuntutan masyarakat yang menginginkan agar pondok pesantren tidak hanya membuka lembaga pendidikan yang mengajarkan materi pengetahuan agama, tapi juga lembaga-lembaga pendidikan yang mengajarkan pengetahuan agama, pengetahuan umum dan keterampilan. ${ }^{16}$

\section{Sistem Kepemimpinan}

Lazimnya sebuah lembaga kependidikan, dalam perencanaan, pelaksanaan dan evaluasi programnya selalu ditentukan secara bersama-sama antara anggota dan pimpinan lembaga. Pesantren Buntet, sebagai lembaga pendidikan Islam, yang menyelenggarakan dua bahkan tiga jenis pendidikan (pendidikan keagama-an, keumuman dan kejuruan) masing-masing lembaga pendidikan tersebut memiliki kepemimpinan dengan programnya yang berbeda-beda. Namun ketiga jenis lembaga pendidikan ini, dalam pertanggung jawaban programnya sangat ditentukan oleh sistem kepemimpinan Pesantren.

Sistem kepemimpinan yang berlangsung di Pondok Pesantren Buntet, secara umum juga terjadi di beberapa Pesantren tradisional lainnya yaitu selalu dipimpin oleh Kyai keturunan dari Kyai pendiri Pesantren (mbah Muqayim atau K. Muta'ad). Namun dipelajari secara mendasar, sistem kepemimpinan di Pondok Pesantren Buntet memi-liki ciri khas tersendiri. Kekhasan ini terjadi, karena latar belakang berdirinya Pondok Pesantren Buntet yang didirikan oleh seorang Kyai (mbah Muqayim) yang berasal dari keluarga Kesultanan Cirebon, sehingga dalam mengendalikan kepemimpinannya tampak seperti mengendalikan sebuah kerajaan yakni diutamakan kepada Kyai putra dari istri pertama. Ini dapat diperhatikan, antara lain dari sebutan "Buntet Pesantren" dan suasana daerah.

Sistem kepemimpinan yang dibangun atas dasar keturunan dan senioritas, biasanya berakibat pada sikap pemimpin yang otoriter terhadap anggotanya baik dalam perencanaan maupun dalam pelaksanaan program kerja. Pondok Pesantren Buntet dipelajari dari sejarahnya, ia didirikan oleh para Kyai keturunan dari kesultanan (kerajaan) Cirebon, sehingga dinilai ada kemiripan dalam menjalankan kepemimpinannya. ${ }^{17}$

\footnotetext{
${ }^{16}$ Dokumentasi diperoleh dari pondok pesantren Buntet Cirebon, diambil tanggal 10 September 2017.

${ }^{17}$ Dokumentasi diperoleh dari pondok pesantren Buntet Cirebon, diambil tanggal 10 September 2017.
} 


\section{Wardah Nuroniya}

\section{HASIL DAN PEMBAHASAN}

Pembahasan mengenai feminisme dalam pesantren, sebagaimana telah dijelaskan dalam kerangka konseptual, bahwa masih menjadi sesuatu yang "tabu" untuk dibicarakan. Meskipun dalam realisasinya, unsur-unsur yang berkenaan dengan feminisme telah muncul seperti peranan dan partisipasi perempuan dalam pengembangan kualitas pesantren. Beberapa hal yang perlu dibenahi dalam pembahasan mengenai feminisme adalah bentuk resistensi atau perlawanan terhadap laki-laki melainkan memberikan ruang terbuka bagi perempuan untuk berpartisipasi dalam berbagai ruang sosial dan keagamaan. Dalam penelitian ini, ada tiga hal yang menjadi temuan penelitian sebagaimana di bawah ini.

\section{Peranan Perempuan di Pondok Pesantren Buntet Cirebon}

Beberapa penelitian mengenai perempuan dalam pesantren, terdapat beragam persepsi dan stigma yang muncul. Sebagian dari mereka menilai kesetaraan antara lakilaki dan perempuan adalah sesuatu yang tidak mungkin dan tidak pantas. Laki-laki mempunyai kedudukan, beban, tanggung jawab lebih tinggi daripada perempuan. Pada umumnya laki-laki diberi kelebihan khusus sebagai pemimpin sebagaimana termaktub dalam al-Qur'an dan hadis. Namun ada juga persepsi yang berbeda, yang menyatakan kesetaraan gender sangat perlu dan harus dilakukan oleh setiap manusia. Bahkan, di pesantren sendiri sekarang telah muncul kontestasi perspektif antara pandangan tradisional yang resisten/menolak ide kesetaraan gender berdampingan dengan pandangan reformatif yang mengiyakan adanya ide kesetaraan gender. ${ }^{18}$ Munculnya pandangan reformatif di kalangan pesantren merupakan dinamika yang mengarah pada makin terbukanya ruang bagi perempuan di lingkungan pesantren. Biasanya pandangan itu muncul dari para aktivis perempuan yang sudah menimba ilmu di Barat atau mengadopsi keilmuan Barat.

Berkenaan dengan peranan perempuan di pondok pesantren Buntet Cirebon, peneliti mewawancarai salah satu pengurus, yang menyatakan bahwa:

“Sebenarnya ruang bagi perempuan sudah ada, cuman sebatas urusan perempuan saja seperti mengorganisir dan mengajar santri putri. Bahkan, ada beberapa perempuan yang menjadi bu Nyai atau mengasuh pondok putri. Namun, pada umumnya kepengelolaan pesantren ini didominasi oleh laki-laki karena mereka

${ }^{18}$ Siti Malikhah Towaf, "Peran Perempuan, Wawasan Gender dan Implikasinya terhadap Pendidikan di Pesantren" dalam Jurnal Ilmu Pendidikan, Jilid 15, Nomor 3, Oktober 2008, h. 140. 


\section{Wardah Nuroniya}

lebih kompeten dan kebetulannya jumlah perempuan di sini lebih sedikit dibandingkan lak-laki."19

Wawancara di atas menunjukkan bahwa perempuan sebenarnya sudah mulai mendapatkan ruang tersendiri tetapi karena kompetensi dan sumber daya manusia masih minim maka ruang bagi perempuan pun sangat terbatas. Masyarakat yang ada di pesantren ini tidak begitu fanatik atau resisten terhadap wacana feminisme, hanya saja memang dari pihak perempuan sendiri yang memang sumber dayanya masih terbatas.

Peneliti sendiri selama melakukan observasi di pondok pesantren Buntet Cirebon tidak menemukan adanya ketimpangan gender yang sangat kentara, melainkan masih minimnya peranan perempuan dalam kepengelolaan pesantren tersebut. Peneliti menyimak adanya pemahaman tentang gender yang makin terbuka di pesantren itu yaitu dengan ditandainya keterlibatan perempuan dalam program kegiatan pesantren, dan bahkan dalam hal kepemimpinan di pesantren itu meskipun pada skala yang kecil.20 Dengan kenyataan itu, wacana tentang feminisme sebenarnya sudah mulai mengemuka dan menjadi salah satu pembicaraan yang hangat dan tidak dapat dikesampingkan. ${ }^{21}$

Keberadaan pesantren seperti itu, dan termasuk beberapa pesantren di Cirebon,,22 saat ini menghadapi dua pilihan dilematis yaitu antara tetap mempertahankan nilai-nilai tradisinya atau mengikuti perkembangan dengan resiko kehilangan identitas kulturalnya. ${ }^{23}$ Pilihan itu sepertinya ingin memisahkan peran laki-laki dan perempuan pada ruang yang benar-benar berbeda. Padahal tidak harus memisahkan antara keduanya, yaitu dengan memberikan tanggung jawab sesuai dengan kompetensinya. Dengan kerjasama yang baik, bahkan antara laki-laki dan perempuan dapat menghasilkan hasil yang maksimal dan berbeda dengan pesantren lainnya karena bagaimanapun perempuan mempunyai sentuhan tersendiri dalam menyelesaikan pekerjaan dan tanggung jawabnya.

Produktivitas dan karya-karya perempuan sekarang ini secara langsung dan tidak langsung telah menjadi kerangka paradigma pengkajian hak-hak perempuan dalam Islam. Lebih dari itu, perkembangan tersebut juga semakin membulatkan tekad dan komitmen

${ }^{19}$ Wawancara dengan pengurus pondok pesantren Buntet Cirebon pada tanggal tanggal 21 September 2017.

${ }^{20}$ Observasi yang dilakukan di pondok pesantren Buntet Cirebon pada tanggal tanggal 10 dan 21 September 2017.

21 Bani Syarif Maula, "Keniscayaan Penggunaan Analisis Gender dalam Studi al-Ahwāl asySyakhsiyyah", Al-Ahwal, Vol. 4, No. 1, 2011.

22 Observasi yang dilakukan pondok pesantren Babakan Ciwaringin Cirebon pada tanggal tanggal 27 September 2017.

${ }^{23}$ Yasmadi, Modernisasi Pesantren (Jakarta: Ciputat Press, 2002), h. 99. 


\section{Wardah Nuroniya}

untuk berjuang secara praksis liberatif dalam mengakomodasi dan membebaskan perempuan dari domestifikasi, subordinasi, dan diskriminasi yang selama ini membelenggu kebebasan perempuan. ${ }^{24}$ Dengan karya-karya itu nampak sekali perempuan telah melakukan perjuangan keras untuk mengangkat harkat dan martabat kaum perempuan secara umum. Perdebatan selalu terjadi disaat karya-karya itu sedang dibuat atau bahkan telah dibuat karena masih ada belenggu kultural (baca: patriarkhal) yang belum dapat lepas sepenuhnya dari masyarakat.

Berdasarkan pembahasan di atas maka peneliti dapat mengambil benang merah bahwa peran dan keterlibatan perempuan di pondok pesantren Buntet Cirebon dan pondok pesantren Babakan Ciwaringin Cirebon masih sebatas partisipatoris dalam kerangka struktural fungsional. Peran semacam ini sebenarnya masih mendapatkan kritikan keras dari kelompok feminis karena dianggap mempraktikkan peran sosial berdasarkan jenis kelamin. Secara umum, laki-laki diposisikan dalam urusan publik dan perempuan diposisikan dalam urusan domestik, khususnya dalam masalah reproduksi. Peran tersebut masih membatasi antara kapasitas laki-laki dan perempuan di lingkungan pesantren. Dapat pula dikatakan, budaya patriarkhal masih menyisakan banyak tradisi di pesantren yang tidak dapat hilang dalam waktu yang relatif sekejap.

\section{Pengembangan Nilai-Nilai Feminisme di Pondok Pesantren Buntet Cirebon}

Nilai-nilai feminisme dalam pesantren sebenarnya telah muncul berbarengan dengan terbukanya ruang partisipasi perempuan di pesantren. Ketimpangan gender yang terjadi di pesantren merupakan warisan budaya para pendahulunya, yang kemudian dikuatkan oleh legitimasi tafsir agama. Superior laki-laki sebagai warisan budaya pra Islam belum sepenuhnya terkikis oleh referensi budaya islami yang dilakukan Nabi Muhammad Saw. Sebab itu, pemahaman terhadap ajaran Islam harus disesuaikan dengan konteks sosiologis, dengan prinsip-prinsip keadilan, kesetaraan, kemaslahatan dan kerahmatan untuk semua umat manusia, tanpa harus dibatasi oleh jenis kelamin, laki-laki atau perempuan. ${ }^{25}$ Pemahaman itu menekankan pada penggabungan antara teks dan konteks mengenai gender sehingga penempatan antara laki-laki dan perempuan tidak mengalami ketimpangan, melainkan justru muncul keseimbangan di antara keduanya.

Pondok pesantren Buntet Cirebon dapat dikategorikan sebagai pesantren yang sudah semi modern. Selain telah berdiri lembaga pendidikan formal, juga munculnya

24 Jamhari dan Ismatu Ropi (ed.), Citra Perempuan dalam Islam: Pandangan Ormas Keagamaan (Jakarta: Gramedia Utama, 2003), h. 4-5.

${ }^{25}$ Siti Malikhah Towaf, "Wawasan Gender dan Peran Produktif Perempuan Pesantren" dalam Jurnal Aplikasi Manajemen, Volume 6, Nomor 2, Agustus 2008, h. 24. 


\section{Wardah Nuroniya}

pemahaman yang menempatkan perempuan sebagai individu yang layak memegang amanah di lingkungan pesantren tersebut. Menurut salah seorang pengurus, menyatakan bahwa:

“Di pesantren ini telah menerapkan sistem yang terbuka bagi perempuan untuk mengembangkan partisipasi dan kreasinya. Setidaknya, pesantren ini telah menempatkan perempuan sebagaimana mestinya sesuai hak dan kewajiban yang dimilikinya."26

Wawancara di atas menegaskan bahwa perbedaan perlakuan atau ketimpangan gender sebagai warisan budaya terdahulu mulai hilang secara perlahan dan lebih menempatkan peran laki-laki dan perempuan sesuai kapasitas dan kompetensinya. Nilainilai feminisme -kalau boleh disebutkan- telah tumbuh dan berkembang meskipun secara implisit. Hal itu lebih dikarenakan masih banyaknya sumber daya laki-laki yang memegang peranan strategis dan demi kestabilan organisasi yang dijalankan di pesantren tersebut.

Peneliti juga mengamati secara langsung munculnya nilai-nilai feminisme di pesantren tersebut, yang agak berbeda dengan kondisi beberapa tahun sebelumnya. Budaya patriarkhal sebagai warisan budaya pesantren tersebut, lambat laun mulai bergeser ke arah profesionalisme kerja, meskipun pada tampuk kepemimpinan di pesantren masih didominasi oleh kaum laki-laki. ${ }^{27}$ Peneliti memaknai bahwa telah terjadi pergeseran paradigma berpikir dari patriarkhalisme ke arah profesionalisme. Pergeseran itu makin terbuka karena pesantren ini telah menerapkan sistem pesantren dan keorganisasian modern. Hal ini seperti dinyatakan oleh salah seorang pengurus menyatakan bahwa:

"Pada pesantren Buntet Cirebon pada umumnya perempuan sudah sadar diri akan kiprah dan perannya dalam berbagai sektor bidang kehidupan, tetapi masih dalam batas-batas tertentu karena masih terhambat adanya paradigma dan budaya patriarkhi yang mengakar. Seperti adanya pemberian awal tentang pengetahuan peran kepada anak-anak tentang perbedaan peran laki-laki dan perempuan, sejak kecil diberikan konsepsi bahwa laki-laki harus menjadi kuat dan harus bisa bertanggung jawab karena akan menjadi sandaran keluarga dan masyarakat, tetapi sebaliknya perempuan bisa menyandarkan dirinya dan kehidupannya

\footnotetext{
2017.

${ }^{26}$ Wawancara dengan pengurus pondok pesantren Buntet Cirebon pada tanggal tanggal 21 September

27 Observasi yang dilakukan di pondok pesantren Buntet Cirebon pada tanggal tanggal 10 dan 21 September 2017.
} 
terhadap laki-laki. Konsepsi awal ini yang akan berpengaruh dan menuntun mereka kepda perkembangan hidupnya hingga dewasa."28

Wawancara di atas makin mempertegas bahwa nilai-nilai feminisme telah berkembang di pesantren-pesantren, khususnya pada pesantren di Cirebon. Nilai-nilai itu berkembang secara perlahan dan tidak jarang mengalami kontroversi. Hal itu disebabkan karena budaya patriarkhi sudah cukup mengakar di kalangan pesantren.

Berdasarkan pada pembahasan di atas maka dapat disimpulkan bahwa nilai-nilai feminisme telah berkembang secara formal di pondok pesantren Buntet Cirebon. Dalam artian telah ada pengakuan secara formal bahwa perempuan mendapatkan ruang untuk mengembangkan peranan dan partisipasinya di lingkungan pesantren. Sedangkan secara kultural, masih terdapat sisa-sisa budaya patriarkhi yang tidak mudah dihilangkan dari pesantren meskipun telah ada perubahan sedikit demi sedikit.

\section{Pengaruh Nilai-Nilai Feminisme Terhadap Doktrin dan Tradisi Pesantren di Pondok Pesantren Buntet Cirebon}

Budaya patriarkhi yang masih membudaya di lingkungan pesantren telah menjadi momok menakutkan bagi para aktivis feminis. Kondisi seperti itu telah mengibarkan perjuangan bagi para perempuan untuk meraih kebebasan (emansipasi) dan melepaskan diri dari belenggu ikatan apa pun. Transformasi sosial yang diperlukan untuk mengatasi hal tersebut adalah proses dekonstruksi peran gender dalam seluruh aspek kehidupan, di mana terefleksi perbedaan-perbedaan gender yang telah melahirkan ketidakadilan gender. Selanjutnya terjadi rekonstruksi sehingga tercipta hubungan yang secara fundamental baru dan lebih baik. Kultur seperti itu yang menghegemoni kaum perempuan harus diubah menjadi struktur nonrepresif, yang lebih membebaskan. ${ }^{29}$ Dengan realitas itulah diperlukan adanya budaya yang membebaskan bagi kaum perempuan dalam mengembangkan peranan dan partisipasinya.

Berkembangnya nilai-nilai feminisme di pondok pesantren Buntet Cirebon dan pondok pesantren Babakan Ciwaringin Cirebon sedikit banyaknya telah mengubah pola pikir dan sikap masyarakat pesantren menjadi lebih egaliter, khususnya terhadap perempuan. Hal itu sesuai dengan pernyataan salah seorang pengurus pondok pesantren Buntet Cirebon, yang menyatakan bahwa:

2017.

${ }^{28}$ Wawancara dengan pengurus pondok pesantren Buntet Cirebon pada tanggal tanggal 27 September

${ }^{29}$ Siti Muslikhati, Feminisme dan Pemberdayaan, h. 22. 30-31. 


\section{Wardah Nuroniya}

"Nilai-nilai feminisme telah memengaruhi sebagian masyarakat di pesantren ini lebih terbuka terhadap peran dan partisipasi perempuan, bahkan sebagian yang lain menerima dipimpin oleh seorang perempuan apabila memang layak dan kompeten."30

Hal itu hampir senada dengan yang disampaikan oleh pengurus pondok Buntet Pesantren Cirebon, yang menyatakan bahwa:

"Dengan adanya pemahaman mengenai feminisme, mulai ada perubahan bagi santri dan pengurus pondok dalam menyikapi partisipasi perempuan. Meskipun perubahan itu tidak terlalu kentara, tetapi perempuan di pesantren ini mulai mendapatkan ruang tersendiri dan lebih terbuka dari masa sebelumnya."31

Hasil kedua wawancara di atas telah menunjukkan bahwa nilai-nilai feminisme telah mengubah pola pikir dan sikap masyarakat pesantren menjadi lebih egaliter dalam memandang perempuan. Termasuk juga dalam hal ini adalah kajian-kajian yang dilakukan di kedua pesantren itu telah terjadi diskursus yang hangat dan relevan dengan kondisi sekarang mengenai gender.

Berdasarkan pemahaman di atas maka peneliti menyimpulkan bahwa pengaruh nilai-nilai feminisme terhadap doktrin dan tradisi pesantren adalah munculnya pemahaman yang lebih egaliter terhadap eksistensi perempuan. Begitu pula dengan tradisi pesantren, mulai ada pergeseran dari tradisi yang lebih mengutamakan peran lakilaki dari pada perempuan (baca: budaya patriarkhi) menjadi tradisi egalitarianisme dalam memandang perempuan. Pada tahapan selanjutnya, perempuan tidak lagi dianggap sebagai subordinat laki-laki tetapi menjadi pribadi yang bebas dan mandiri.

\section{SIMPULAN}

Penelitian mengenai feminisme dalam pesantren yang digambarkan melalui narasi pemberdayaan perempuan di pondok pesantren Buntet Cirebon, mempunyai tiga kesimpulan sebagai berikut:

1. Peranan perempuan di pondok pesantren Buntet Cirebon masih sebatas partisipatoris dalam kerangka struktural fungsional. Peran semacam ini sebenarnya mendapatkan masih mendapat kritikan keras dari kelompok feminis karena dianggap mempraktikkan peran sosial berdasarkan jenis kelamin. Secara umum, laki-laki diposisikan dalam urusan publik dan perempuan diposisikan dalam urusan domestik,

\footnotetext{
2017.

${ }^{30}$ Wawancara dengan pengurus pondok Buntet pesantren Cirebon pada tanggal tanggal 21 September

${ }^{31}$ Wawancara dengan pengurus pondok Cirebon pesantren Cirebon pada tanggal tanggal 27 September 2017.
} 


\section{Wardah Nuroniya}

khususnya dalam masalah reproduksi. Peran tersebut masih membatasi antara kapasitas laki-laki dan perempuan di lingkungan pesantren. Dapat pula dikatakan, budaya patriarkhal masih menyisakan banyak tradisi di pesantren yang tidak dapat hilang begitu saja. Kesimpulan ini berdasarkan pada wawancara dan observasi yang telah dilakukan oleh peneliti.

2. Pengembangan nilai-nilai feminisme di pondok pesantren Buntet Cirebon berlaku secara formal di pondok pesantren Buntet Cirebon. Dalam artian telah ada pengakuan secara formal bahwa perempuan mendapatkan ruang untuk mengembangkan peranan dan partisipasinya di lingkungan pesantren. Sedangkan secara kultural, masih terdapat sisa-sisa budaya patriarkhi yang tidak mudah dihilangkan dari pesantren meskipun telah ada perubahan sedikit demi sedikit. Kesimpulan ini berdasarkan pada wawancara dan observasi yang telah dilakukan oleh peneliti.

3. Pengaruh nilai-nilai feminisme terhadap doktrin dan tradisi pesantren di pondok pesantren Buntet Cirebon adalah munculnya pemahaman yang lebih egaliter terhadap eksistensi perempuan. Begitu pula dengan tradisi pesantren, mulai ada pergeseran dari tradisi yang lebih mengutamakan peran laki-laki daripada perempuan menjadi tradisi egalitarianisme dalam memandang perempuan. Pada tahapan selanjutnya, perempuan tidak lagi dianggap sebagai subordinat laki-laki tetapi menjadi pribadi yang bebas dan mandiri. Kesimpulan ini berdasarkan pada wawancara dan observasi yang telah dilakukan oleh peneliti.

\section{DAFTAR PUSTAKA}

Azwar, Saifuddin. Metode Penelitian. Yogyakarta: Pustaka Pelajar, 2007, Cet. VII.

Dhofier, Zamakhsyari. Tradisi Pesantren: Studi tentang Pandangan Hidup Kyai. Jakarta: LP3ES, 1982.

Engineer, Asghar Ali. Pembebasan Perempuan, terj. Agus Nuryatno. Yogyakarta: LKiS, 2003.

Ismail, Nurjannah. Perempuan dalam Pasungan: Bias Laki-laki dalam Penafsiran. Yogyakarta: LkiS, 2003.

Jamhari dan Ismatu Ropi (ed.). Citra Perempuan dalam Islam: Pandangan Ormas Keagamaan. Jakarta: Gramedia Utama, 2003.

Maula, Bani Syarif. "Keniscayaan Penggunaan Analisis Gender dalam Studi al-Ahwāl asySyakhsiyyah", Al-Ahwal, Vol. 4, No. 1, 2011. 
Wardah Nuroniya

Megawangi, Ratna. Membiarkan Berbeda: Sudut Pandang Baru tentang Relasi Gender. Bandung: Mizan, 1999, Cet. I.

Qomar, Mujamil. Pesantren: Dari Transformasi Metodologi Menuju Demokratisasi Institusi. Jakarta: Erlangga, 2005.

Towaf, Siti Malikhah. "Peran Perempuan, Wawasan Gender dan Implikasinya terhadap Pendidikan di Pesantren" dalam Jurnal Ilmu Pendidikan, Jilid 15, No. 3, Oktober 2008.

Towaf, Siti Malikhah. "Wawasan Gender dan Peran Produktif Perempuan Pesantren" dalam Jurnal Aplikasi Manajemen, Volume 6, Nomor 2, Agustus 2008.

Venny, Adriana (ed.). "Pentingnya Metodologis Feminis di Indonesia", dalam Jurnal Perempuan, No. 48, Juli, 2006.

Wahid, Abdurrahman. Menggerakkan Tradisi: Esai-esai Pesantren. Yogyakarta: LKiS, 2001.

Yasmadi. Modernisasi Pesantren. Jakarta: Ciputat Press, 2002. 